\title{
Selected Diptera of City Park Kolmanka, Prešov (Slovakia)
}

\author{
Jozef Oboňa, Paul L. Th. Beuk, Kateřina Dvořáková, Libor Dvořák, Patrick Grootaert, \\ Jean-Paul Haenni, Jan Ježek, Laura Mlynárová, Ruud van der Weele \& Peter Manko
}

Selected Diptera of City Park Kolmanka, Prešov (Slovakia). - Acta Mus. Siles. Sci. Natur. 70: 125-134, 2021.

\begin{abstract}
In total 65 Diptera species from 20 families (Anisopodidae (2 spp.), Asilidae (1), Bibionidae (1), Clusiidae (1), Culicidae (8), Dolichopodidae (7), Drosophilidae (4), Dryomyzidae (1), Empididae (2), Heleomyzidae (5), Hybotidae (5), Lauxaniidae (4), Limoniidae (9), Opomyzidae (2), Pallopteridae (2), Psychodidae (6), Rhagionidae (2), Scatopsidae (1), Trichoceridae (1) and Ulidiidae (1)) were recorded. The species Drapetis flavipes Macquart, 1834 (Hybotidae), is recorded for the first time in Slovakia. Ten species belong among uncommon or rare (namely: Atypophthalmus (Atypophthalmus) inustus (Meigen, 1818), Calliopum splendidum Papp, 1978, Dioctria linearis (Fabricius, 1787), Cheilotrichia (Empeda) neglecta (Lackschewitz, 1927), Chrysopilus asiliformis (Preyssler, 1791), Ochlerotatus (Ochlerotatus) nigrinus (Eckstein 1918), Philosepedon (Philosepedon) austriacum Vaillant, 1974, Suillia variegata (Loew, 1862), Toxoneura modesta (Meigen, 1830) and Trichomyia urbica Curtis, 1839). On the other hand, two invasive species are also reported. Drosophila (Sophophora) suzukii (Matsumura, 1931) is an invasive crop pest and Aedes (Finlaya) japonicus japonicus (Theobald, 1901) is an invasive biting pest, a potential vector for various diseases. City parks are also important from the point of view of Diptera biodiversity and more attention needs to be paid to them.
\end{abstract}

Key words: flies, faunistics, interesting findings, first record, city park biodiversity

\section{Introduction}

The role of urban parks for the sustainability of a city is well known. The presence of natural areas contributes to the quality of human life in many ways. Besides many environmental and ecological services, urban nature provides important social and psychological benefits to human societies, enriching human life with meaning and emotions (e.g. Chiesura 2004). On the other hand, many insect groups can also benefit from this environment, e.g. flies, especially those of the families Phoridae (Hartop et al. 2015), Drosophilidae (Silva et al. 2005), Sepsidae (Ang et al. 2017) and other families (e.g. in Patitucci et al. 2015), or beetles (Komaromi et al. 2018), etc. However, in general, mosquitoes are the best studied insect group in these areas (e.g. Medeiros-Sousa et al. 2013, 2015, Paula et al. 2015, Ceretti-Junior et al. 2016, Carvalho et al. 2017, etc.).

From Central Europe, and especially from Slovakia, there are also several notes about insect research in urban nature (e.g. Malenovský \& Kment 2004, Jendek et al. 2009; Šustek \& Stanko 2012, ̌̌íha 2017, Pavlíková et al. 2020). Several works have also been published directly from the territory of the city of Prešov (Oboňa et al. 2017a,b, 2020, 2021, Maslova et al. 2018, van der Weele et al. 2018, Negrobov et al. 2019, 2020).

The aim of this paper is to spread knowledge about selected Diptera fauna of City Park Kolmanka (Prešov, Slovakia). 


\section{Material and methods}

Diptera were collected by J. Oboňa, L. Mlynárová and P. Manko in the growing season in 2021 (exactly during months of May to October) by sweep-netting (15 minutes of netting for one sampling) for collection from vegetation growing in City Park Kolmanová záhrada (so-called "Kolmanka") (4859'30.0"N 21¹3'34.9"E, $247 \mathrm{~m}$ a.s.1., Fig. 1). The collection dates are as follows: 1.v.2021, 6.vi.2021, 5.vii.2021, 13.viii.2021, 12.ix.2021, 17.x.2021. The locality is a mixed forest (Betula, Fagus, Quercus, Picea, Acer, Pinus, etc.) with sunny stands. The captured specimens were preserved in $75 \%$ ethanol in the field.

In the laboratory, Jozef Oboňa identified male mosquitos (Culicidae) using Becker et al. (2010), also taking in account Harbach et al. (2017); Drosophilidae by Bächli et al. (2004), also taking in account Calabria et al. (2012); Limoniidae by Oosterbroek (2021) and Podenas et al. (2006); Psychodidae using Withers (1989), Jung (1956) and original papers with descriptions of species, e.g. Ježek (1977, 1985, 1990, 1995); and Trichoceridae using Krzemińska (2020). This material in alcohol is deposited in the collection of the Laboratory and Museum of Evo-lutionary Ecology, Department of Ecology, University of Prešov (LMEE PO). Libor Dvořák identified Anisopodidae (Söli \& Rindal 2014), Asilidae (Geller-Grimm 2003), Bibionidae (Haenni 1982), Clusiidae (Stackelberg 1970), Opomyzidae (Drake 1993), Pallopteridae (Ozerov 2009), Rhagionidae (Rozkošný \& Spitzer 1965) and Ulidiidae (Richter 1970). This material in alcohol is deposited in the private collection of L. Dvořák. Paul L. Th. Beuk identified Dolichopodidae (Chandler \& Negrobov 2008, Grichanov 2006, Negrobov \& Naglis 2016). This material in alcohol is deposited in the collection of the Natuurhistorisch Museum Maastricht, Maatricht, the Netherlands. Kateřina Dvořáková identified Dryomyzidae (Ozerov 1987), Heleomyzidae (Papp 1981) and Lauxaniidae (Semelbauer 2016). This material in alcohol is deposited in the private collection of K. Dvořáková. Ruud van der Weele and Patrick Grootaert used keys (e.g. Grootaert and Chvála 1992; Chvála 2005) for identifying the families Empididae and Hybotidae. This material is deposited in the private collection of R. van der Weele. Jean-Paul Haenni identified the Scatopsidae (Cook 1974), and the material deposited in the collection of Muséum d'histoire naturelle Neuchâtel (MHNN).

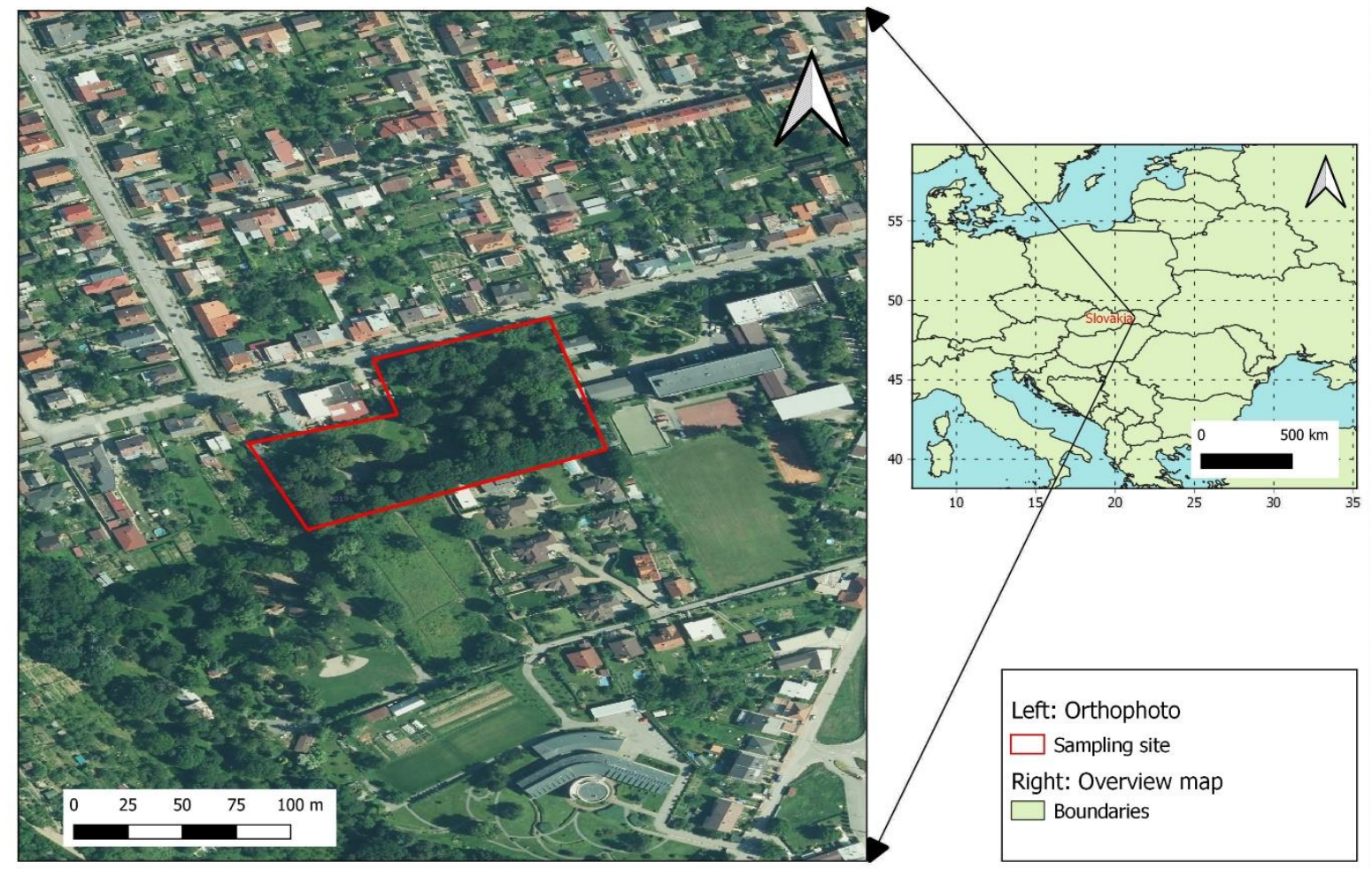

Fig 1: Map of the collecting area. 


\section{Results}

\section{ANISOPODIDAE}

Sylvicola cinctus (Fabricius, 1787)

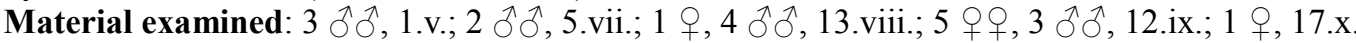

Sylvicola fuscatus (Fabricius, 1775)

Material examined: $1 \hat{\partial}$, 6.vi. (all samples 2021); $3 \hat{\jmath} \widehat{\partial}, 2$ 우, 5.vii.; 1 ô, 13.viii.

\section{ASILIDAE}

Dioctria linearis (Fabricius, 1787)

Material examined: 1 , , 5.vii.

Note. Relatively rare species of thermophilic sunny stands.

\section{BIBIONIDAE}

Dilophus febrilis (Linnaeus, 1758)

Material examined: 1 , $1 . v$.

\section{CLUSIIDAE}

Clusiodes albimanus (Meigen, 1830)

Material examined: $1 \stackrel{+}{\circ}, 1 \hat{\jmath}, 12$. ix.

\section{CULICIDAE}

Aedes (Aedimorphus) vexans (Meigen 1830)

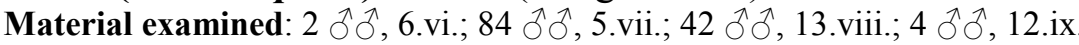

Aedes (Finlaya) japonicus japonicus (Theobald, 1901)

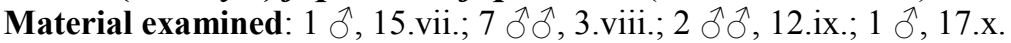

Note: An invasive biting pest, a potential vector for various diseases (e.g. Čabanová et al. 2021).

Anopheles plumbeus (Stephens 1828)

Material examined: $2 \hat{\jmath} \widehat{\jmath}$, 13.viii.

Culex (Culex) pipiens pipiens Linnaeus 1758

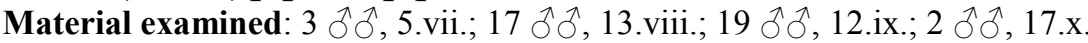

Culiseta (Culiseta) annulata (Schrank 1776)

Material examined: $1 \hat{\sigma}$, 13.viii.

Ochlerotatus (Finlaya) geniculatus (Olivier 1791)

Material examined: $4 \hat{\sigma}$, 5.vii.

Ochlerotatus (Ochlerotatus) communis (De Geer 1776)

Material examined: $1 \hat{\partial}$, 6.vi.; $1 \hat{\partial}$, 5.vii.

Ochlerotatus (Ochlerotatus) nigrinus (Eckstein 1918)

Material examined: $1 \hat{\partial}$, $6 . v i$; $8 \hat{\partial} \hat{\jmath}$, 5.vii.

Note: Not widely distributed and not a numerous species.

\section{DOLICHOPODIDAE}

Chrysotimus molliculus (Fallén, 1823)

Material examined: 3 우, 13.viii.

Medetera jacula (Fallén, 1823)

Material examined: 1 ( (cf.), 13.viii.

Medetera truncorum Meigen, 1824

Material examined: $1 \hat{\partial}, 2$ q $ᄋ$, 5.vii.; $1 \hat{\jmath}, 1$ ㅇ, 13.viii.; $1 \hat{\jmath}, 12$.ix. 
Neurigona quadrifasciata (Fabricius, 1781)

Material examined: $1 \curvearrowright, 1$ ㅇ, 6.vi; 2 우, 5.vii.

Sciapus platypterus (Fabricius, 1805)

Material examined: $1 \hat{\partial}$, 5.vii.

Xanthochlorus ornatus (Haliday, 1832)

Material examined: $1 \hat{\delta}$, 6 .vi.

Xanthochlorus tenellus (Wiedemann, 1817)

Material examined: $2 \hat{\jmath} \widehat{\partial}, 1$, , 5.vii.; 1 ㅇ, 13.viii.

\section{DROSOPHILIDAE}

Drosophila (Drosophila) busckii Coquillett, 1901

Material examined: 1 ก , 12.ix.

Drosophila (Sophophora) suzukii (Matsumura, 1931)

Material examined: $2 \hat{\jmath}, 12$. ix.; 1 + , 17.x.

Note: An invasive crop pest (e.g. Mariychuk et al. 2020).

Chymomyza amoena (Loew, 1862)

Material examined: $2 \widehat{\partial}, 12$.ix.

Leucophenga maculata (Dufour, 1839)

Material examined: $1 \hat{\delta}, 12$.ix.; $1 \hat{\jmath}, 17 . x$.

DRYOMYZIDAE

Dryope flaveola (Fabricius, 1794)

Material examined: $1 \hat{\delta}, 17 . x$.

\section{EMPIDIDAE}

Empis (Empis) aestiva Loew, 1867

Material examined: 1 ô, 1 + , 5.vii.

Empis (Xanthempis) lutea Meigen, 1804

Material examined: $1 \delta$, 5.vii.

Suillia bicolor (Zetterstedt, 1838)

HELEOMYZIDAE

Material examined: $2 \hat{\delta} \delta$, 2 우, 17.x.

Suillia fuscicornis (Zetterstedt, 1847)

Material examined: $1 \stackrel{+}{\circ}, 12 . i x$.

Suillia pallida (Fallén, 1820)

Material examined: $1 \hat{\jmath}$, 6.vi.; $1 \hat{\jmath}, 17 . x$.

Suillia variegata (Loew, 1862)

Material examined: $1 \hat{\partial}, 12$.ix.

Note: A rare thermophilous species without any clear affinity to the habitat.

Tephrochlamys flavipes (Zetterstedt, 1838)

Material examined: 1 q, 17.x.

\section{HYBOTIDAE}

Drapetis flavipes Macquart, 1834

Material examined: $1 \hat{\partial}$, 5.vii.

Distribution: Austria, Belgium, Croatia, Czech Republic, France, Germany, Italy, Macedonia, Slovenia, Switzerland, Ukraine and North Africa (Chvála 2013, Grootaert et al. 2010). In the Czech Republic known only from Bohemia - see Chvála (2009). First record for Slovakia. 
Elaphropeza ephippiata (Fallén, 1815)

Material examined: $1 \hat{\jmath}$, 5.vii.; $2 \widehat{\partial} \widehat{\partial}$, 13.viii.

Ocydromia glabricula (Fallén, 1816)

Material examined: $1 \hat{\partial}, 1$, 12. ix

Platypalpus ciliaris (Fallén, 1816)

Material examined: $1 \delta$, 17.x.

Tachydromia annulimana Meigen, 1822

Material examined: $3 \hat{\jmath} \widehat{\partial}$, 5.vii.

\section{LAUXANIIDAE}

Calliopum splendidum Papp, 1978

Material examined: 1 + , 12.ix.; 1 q, 17.x.

Note. A rare species of shaded stands, mainly in beech forest (Semmelbauer 2016).

Meiosimyza decempunctata (Fallén, 1820)

Material examined: 1 + , 6.vi; 1 +, 5.vii.; 1 o, 13.viii, 1 ô, 12.ix.

Meiosimyza rorida (Fallén, 1820)

Material examined: 1 , 13.viii.

Tricholauxania praeusta (Fallén, 1820)

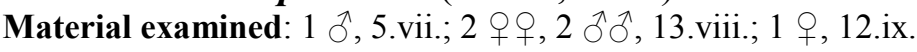

\section{LIMONIDAE}

Achyrolimonia decemmaculata (Loew, 1873)

Material examined: $2 \hat{\jmath}$, 13.viii.

Atypophthalmus (Atypophthalmus) inustus (Meigen, 1818)

Material examined: $1 \hat{\partial}$, 5.vii.; $1 \hat{\partial}$, 13.viii.

Note: An uncommon species.

Dicranomyia (Dicranomyia) modesta (Meigen, 1818)

Material examined: $1 \hat{\partial}$, 13.viii.; $2 \hat{\partial} \widehat{\partial}, 12$.ix.

Dicranoptycha livescens Loew, 1871

Material examined: $1 \hat{\delta}$, 13.viii.

Cheilotrichia (Empeda) neglecta (Lackschewitz, 1927)

Material examined: 1 ô, 12 .ix.

Note: An uncommon species.

Ilisia maculata (Meigen, 1804)

Material examined: $2 \widehat{\partial} \partial^{\lambda}, 12$.ix.

Limonia nubeculosa Meigen, 1804

Material examined: 1 , $12 . \mathrm{ix} ; 3 \hat{\jmath} \sigma^{\lambda}, 17 . x$.

Molophilus (Molophilus) propinquus (Egger, 1863)

Material examined: $2 \hat{\partial} \widehat{\partial}$, 5.vii.; $1 \hat{\partial}$, 13.viii.

Symplecta (Psiloconopa) stictica stictica (Meigen, 1818)

Material examined: 1 , $12 . \mathrm{ix}$.

OPOMYZIDAE

Opomyza florum (Fabricius, 1794)

Material examined: $1 \hat{\jmath}, 12$.ix.

Opomyza germinationis (Linnaeus, 1758)

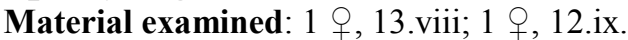




\section{PALLOPTERIDAE}

Palloptera umbellatarum (Fabricius, 1775)

Material examined: $1 \hat{\partial}$, 6 .vi.

Toxoneura modesta (Meigen, 1830)

Material examined: $2 \hat{\jmath} \hat{\sigma}$, 13 .viii.

Note: An uncommon species of thermophilic sunny shrubs and forest margins.

\section{PSYCHODIDAE}

Logima satchelli (Quate, 1955)

Material examined: $3 \stackrel{\partial}{\partial}$, $6 . v i$.

Philosepedon (Philosepedon) austriacum Vaillant, 1974

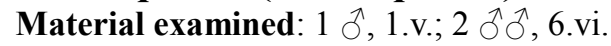

Note Local occurrence, a relatively rare European species (Oboňa \& Ježek 2013).

Philosepedon (Philosepedon) humerale (Meigen, 1818)

Material examined: $4 \hat{\partial} \hat{\partial}$, 12.ix.; 2 ô $\hat{\sigma}$, 17.x.

Tinearia alternata (Say, 1824)

Material examined: $3 \stackrel{\partial}{\partial}$, $6 . v i$.

Trichomyia urbica Curtis, 1839

Material examined: $1 \hat{\jmath}, 1 . v$.

Note: Not a common European species. In Jedlička \& Stloukalová (2001) vulnerable, the current conservation status: CR (Oboňa \& Ježek 2013).

Trichopsychoda hirtella (Tonnoir, 1919)

Material examined: $2 \widehat{\partial} \sigma^{\lambda}$, 13.viii.

\section{RHAGIONIDAE}

Chrysopilus asiliformis (Preyssler, 1791)

Material examined: $1 \hat{\partial}$, 5.vii.; $5 \hat{\partial} \hat{\partial}$, 13.viii.

Note: A typical species of sunny stands at lower elevations.

Rhagio maculatus (De Geer, 1776)

Material examined: $1 \hat{\delta}, 6 . v i$.

\section{SCATOPSIDAE}

Apiloscatopse flavicollis (Meigen, 1818)

Material examined: 3 우우, 17.x.

Note: A common species of wooded areas, with an autumnal flight period.

\section{TRICHOCERIDAE}

Trichocera annulata Meigen, 1818

Material examined: $3 \widehat{\partial} \widehat{\partial}, 17 . x$.

\section{ULIDIIDAE}

Seioptera vibrans (Linnaeus, 1758)

Material examined: $1 \hat{\partial}$, 13.viii.

\section{Conclusion}

In total, 65 Diptera species - more than 340 specimens from 20 families - are recorded. One species, Drapetis flavipes Macquart, 1834, is recorded for the first time for Slovakia; ten species are uncommon or rare, and two species are invasive. The greatest biodiversity of the selected Diptera groups was recorded in August (24 species); the smallest in May (4 species). 
The largest number of captured individuals of the selected Diptera was recorded in July (130 specimens, 23 species), the smallest in May (6 specimens, 4 species). Anisopodidae and Culicidae were present at the site for almost the entire research period. A dominant occurrence at the beginning of the season (May, Jun) was confirmed in Bibionidae, and families Drosophilidae, Opomyzidae, Scatopsidae and Trichoceridae were recorded at the end of growing season (September, October). The mid-season (July, August) was preferred mainly by species from the families e.g. Asilidae, Empididae, Heleomyzidae, Lauxaniidae and Pallopteridae. The most abundant families were Culicidae, with 8 species and 201 specimens, Limoniidae (9 species, 13 specimens) and Dolichopodidae (7 species, 20 specimens). Asilidae, Bibionidae, Clusiidae, Dryomyzidae, Scatopsidae, Trichoceridae and Ulidiidae were present with 1 only species each.

As stated in the introduction, insects can also benefit from environments like city parks. It is even possible to find new and rare species for the local and regional fauna, as well as invasive and non-native species. We can also support the opinion (see also Medeiros-Sousa et al. 2013, 2015, Paula et al. 2015, Ceretti-Junior et al. 2016, Carvalho et al. 2017, etc.) that mosquitoes are the best and most often studied insect group in these areas. In view of the abovementioned results, can be confirm that there are presented a fauna of shaded forests, fauna of forest-steppes and fauna of sunny habitats.

Acknowledgements: We are grateful to Jaroslav Starý (Olomouc, Czech Republic) for valuable consultations on the family Limoniidae. We thank the editor and all anonymous reviewers for their valuable and constructive comments on the first version of the manuscript. This work was supported by the Slovak Scientific Grant Agency under contract No. VEGA-1/0012/20, by the Slovak Research and Development Agency under the contract No. APVV-16-0236 and by the Ministry of Culture of the Czech Republic (DKRVO 2020-2023/5.I.c, National Museum, Prague, 00023272)

\section{References}

Ang Y., Rajaratnam G., Su K.F. \& Meier R. (2017): Hidden in the urban parks of New York City: Themira lohmanus, a new species of Sepsidae described based on morphology, DNA sequences, mating behavior, and reproductive isolation (Sepsidae, Diptera). - ZooKeys 698: 95-111.

Bächli G., Vilela C.R., Andersson Escher S. \& Saura A. (2004): The Drosophilidae (Diptera) of Fennoscandia and Denmark. - Fauna entomologica Scandinavica 39: 1-362.

Becker N., Petric D., Zgomba M., Boase C., Madon M., Dahl C. \& Kaiser, A. (2010): Mosquitoes and their control. Springer Science \& Business Media, 608 pp.

Čabanová V., Boršová K., Svitok M., Oboňa J., Svitková I., Barbušiová E., Derka T., Sláviková M. \& Klempa B. (2021): An unwanted companion reaches the country: the first record of the alien mosquito Aedes japonicus japonicus (Theobald, 1901) in Slovakia. - Parasites \& Vectors 14: 572.

Calabria G., Máca J., Bachli G., Serra L. \& Pascual M. (2012): First records of the potential pest species Drosophila suzukii (Diptera: Drosophilidae) in Europe. - Journal of Applied Entomology 136: 139-147.

Carvalho G.C.D., Ceretti-Junior W., Barrio-Nuevo K.M., Wilk-da-Silva R., de Oliveira Christe R, Paula M.B.D., Vendrami D.P., Multini L.C., Evangelista E., Camargo A.A. \& Souza L.F. (2017): Composition and diversity of mosquitoes (Diptera: Culicidae) in urban parks in the South region of the city of São Paulo, Brazil. - Biota Neotropica 17: e20160274.

Ceretti-Junior W., de Oliveira Christe R., Rizzo M., Strobel R.C., de Matos Junior M.O., de Mello M.H.S.H., Fernandes A., Medeiros-Sousa A.R., de Carvalho G.C. \& Marrelli M.T. (2016): Species composition and ecological aspects of immature mosquitoes (Diptera: Culicidae) in bromeliads in urban parks in the city of São Paulo, Brazil. - Journal of arthropod-borne diseases 10(1): 102-112.

Chandler P.J. \& Negrobov O.P. (2008): The British species of Xanthochlorus Loew, 1857 (Diptera, Dolichopodidae), with description of two new species. - Dipterists Digest, Second Series 15(1): 29-40.

Chiesura A. (2004): The role of urban parks for the sustainable city. - Landscape and urban planning 68(1): 129138. 
Chvála M. (2005): The Empidoidea (Diptera) of Fennoscandia and Denmark. IV Genus Hilara. Fauna Entomologica Scandinavica 40, 234 pp.

- (2009): Hybotidae Fallén, 1816. In: Jedlička L., Kúdela M. \& Stloukalová V. (eds): Checklist of Diptera of the Czech Republic and Slovakia. Electronic ver. 2. http:/www.edvis.sk/diptera2009/families/ hybotidae.htm. Accessed 1.10.2021.

- (2013): Fauna Europaea: Hybotidae. In: Pape T. \& Beuk P. (eds.): Fauna Europaea, ver. 2017.06. https://faunaeu.org/. Accessed 1.10.2021.

Coook E.F. (1974): A synopsis of the Scatopsidae of the Palaearctic. Part III. The Scatopsini. - Journal of natural History 8(1): 61-100.

Drake C.M. (1993): A review of the British Opomyzidae (Diptera). - British Journal of Entomology and Natural History 6: 159-176.

Geller-Grimm F. (2003): Photographic atlas and identification key to the robber flies of Germany (Diptera: Asilidae). http://www.robberflies.info/keyger/htmle/key.html. Accessed 1.10.2021.

Grichanov I.Ya. (2006): A checklist and keys to North European genera and species of Dolichopodidae (Diptera). - Plant Protection News Supplement 2006: 1-120.

Grootaert P. \& Chvála M. (1992): Monograph of the genus Platypalpus (Diptera: Empidoidea, Hybotidae) of the Mediterranean region and the Canary Islands. - Acta Universitatis Carolinae Biologica 36: 1-226.

Grootaert P., Shamshev I. \& Stark A. (2010): Drapetis flavipes Macquart (Diptera, Hybotidae) new for the Belgian fauna, with a re-description of the species and a preliminary key to the West-European species of Drapetis. - Bulletin de la Société Royale Belge d'Entomologie 146: 110-115.

Haenni J.-P. (1982): Révision des espèces européennes du groupe de Dilophus febrilis (L.), avec description d'une espèce nouvelle (Diptera, Bibionidae). - Revue Suisse de Zoologie 89: 337-354.

Harbach R.E., Dallimore T., Briscoe A.G., Culverwell C.L., Vaux A.G. \& Medlock J.M. (2017): Aedes nigrinus (Eckstein, 1918) (Diptera, Culicidae), a new country record for England, contrasted with Aedes sticticus (Meigen, 1838). - ZooKeys 671: 119-130.

Hartop E.A., Brown B.V. \& Disney R.H.L. (2015): Opportunity in our ignorance: urban biodiversity study reveals 30 new species and one new Nearctic record for Megaselia (Diptera: Phoridae) in Los Angeles (California, USA). - Zootaxa 3941 (4): 451-484.

Jedlička L. \& Stloukalová V. (2001): Červený (ekosozoologický) zoznam dvojkrídlovcov (Diptera) Slovenska. In: Baláž D., Marhold K. \& Urban P. (eds): Červený zoznam rastlín a živočíchov Slovenska. - Ochrana prírody, Suppl. 20: 139-142.

Jendek E., Štrba M., Kautman V., Hergovits R. \& Rychlík I. (2009): Monitoring vybraných ohrozených a chránených chrobákov (Coleoptera) na území Bratislavy - východisko k diskusii o druhovej ochrane hmyzu na Slovensku. - Folia faunistica Slovaca 14(2): 17-29.

Ježek J. (1977): Reinstatement of the genus Tinearia Schellenberg (Diptera, Psychodidae). - Acta entomologica bohemoslovaca 74: 232-241.

- (1985): Contribution to the knowledge of a new subtribe Trichopsychodina (Diptera, Psychodidae) from Czechoslovakia. - Acta Museu Nationalis Pragae 40: 65-92.

- (1995): Occasional paper on some interesting Palaearctic moth flies (Diptera, Psychodidae). - Dipterologica bohemoslovaca 7: 85-96.

- (1990): Redescriptions of nine common palaearctic and holarctic species of Psychodini End. (Diptera: Psychodidae). - Acta Entomologica Musei Nationalis Pragae 43: 33-83.

Jung H.F. (1956): Beiträge zur Biologie, Morphologie und Systematik der Europäischen Psychodiden (Diptera). - Deutsche entomologische Zeitschrift (Berlin) N.F. 3: 97-257.

Komaromi N.A., Nikolenko N.Y. \& Puchkov A.V. (2018): The faunistic structure of beetles (Insecta: Coleoptera) in herpetobios of urbocenosis of Kharkiv city (Ukraine). - Ukrainian entomological journal 15(2): 3-21.

Krzemińska E. (2020): Key and atlas to the genus Trichocera Meigen in Europe (Diptera, Trichoceridae). - Acta Zoologica Cracoviensia 64(1): 1-157.

Malenovský I. \& Kment P. (2004): First record of Livilla variegata (Löw, 1881)(Hemiptera: Psylloidea, Psyllidae) in Slovakia. - Biologia (Bratislava) 59(2): 292.

Mariychuk R., Kozeretska I., Serga S., Manko P. \& Oboňa J. (2020): Current state of invasion of Drosophila suzukii (Matsumura, 1931) in Ukraine. - European Journal of Ecology 6(1): 51-57.

Maslova O.O., Negrobov O.P. \& Oboňa J. (2018): A new species of Medetera (Diptera: Dolichopodidae) from Slovakia. - Zoosystematica Rossica 27(2): 196-199.

Medeiros-Sousa A.R., Ceretti-Junior W., de Carvalho G.C., Nardi M.S., Araujo A.B., Vendrami D.P. \& Marrelli M.T. (2015): Diversity and abundance of mosquitoes (Diptera: Culicidae) in an urban park: larval habitats and temporal variation. - Acta tropica 150: 200-209. 
Medeiros-Sousa A.R., Ceretti-Junior W., Urbinatti P.R., Natal D., Carvalho G.C.D., Paula M.B.D., Fernandes A., Mello M.H.S.H.D., Oliveira R.C.D., Orico L.D. \& Gonçalves E.F.B. (2013): Mosquito (Diptera: Culicidae) survey in parks of São Paulo City I. - Biota Neotropica 13(1): 317-321.

Negrobov O.P. \& Naglis S. (2016): Palaearctic species of the genus Medetera (Diptera: Dolichopodidae). Zoosystematica Rossica 25(2): 333-379.

Negrobov O.P., Manko P. \& Oboňa J. (2019): New records of long-legged flies (Diptera: Dolichopodidae) from Slovakia. - Klapalekiana 55(3-4): 235-237.

- (2020): A new species of Systenus Loew (Dolichopodidae, Diptera) from Slovakia. - Acta Musei Silesiae, Scientiae Naturales 69: 161-164.

Oboňa J., Demková D., Kohútová M., Máca J. \& Manko P. (2017a): On the occurrence of Drosophila suzukii (Matsumura, 1931) in Slovakia. - Acta Universitatis Prešoviensis, Folia oecologica 9: 5-10.

Oboňa J., Demková D., Smol'ák R., Dominiak P. \& Ščerbáková S. (2017b): Invertebrates in overlooked aquatic ecosystem in the middle of the town. - Periodicum Biologorum 119: 47-54.

Oboňa J. \& Ježek J. (2014): Prodromus of moth flies (Diptera: Psychodidae) from Slovakia. - Acta Musei Silesiae, Scientiae Naturales 63(3): 1-193.

Oboňa J., Ježek J., Kanašová K. \& Manko P. (2021): Hiding in plain sight: new records and endangered flies (Diptera) from a tree-hole in an urban park (Prešov, Slovakia). - Acta Musei Silesiae, Scientiae Naturales 70: $75-81$.

Oboňa J., Kanašová K., Michalko M. \& Manko P. (2020): The Mosquitoes of Prešov Town (Slovakia) - a pilot study. - Acta Musei Silesiae, Scientiae Naturales 69: 249-257.

Oosterbroek P. (2021): Catalogue of the Craneflies of the World. https://ccw.naturalis.nl/. Accesed 1.10.2021.

Ozerov A.L. (1987): Dipterans of the family Dryomyzidae in the fauna of the USSR. - Bulletin of Moscow Society of Naturalists 92(4): 36-42. [In Russian]

- (2009): Review of the Family Pallopteridae (Dipetera) of the Fauna of Russia. - Russian Entomological Journal 18(2): 129-146. [In Russian]

Papp L. (1981): Tüskésszárnyú - Heleomyzidae (Family - Heleomyzidae). - Fauna Hungariae 149: 1-77.

Patitucci L.D., Mulieri P.R., Domínguez M.C. \& Mariluis J.C. (2015): An inventory of saprophagous Calyptratae (Insecta: Diptera) in urban green spaces of Buenos Aires City. - Revista del Museo Argentino de Ciencias Naturales nueva serie 17(1): 97-107.

Paula M.B.D., Fernandes A., Medeiros-Sousa A.R., Ceretti-Junior W., Christe R., Stroebel R.C., Pedrosa L., Almeida R.M.M.D.S., Carvalho G.C.D., Pereira U.D. \& Jacintho M.C.D.O. (2015): Mosquito (Diptera: Culicidae) fauna in parks in greater São Paulo, Brazil. - Biota Neotropica 15: e20140026.

Pavlíková A., Klesniaková M. \& Holecová M. (2020): The occurrence of false honey ant (Prenolepis nitens) in the urban greenery of the Bratislava city (SW Slovakia). - Folia faunistica Slovaca 25: 1-7.

Podenas S., Geiger W., Haenni J. P. \& Gonseth Y. (2006): Limoniidae \& Pediciidae. Fauna Helvetica 14: 1375.

Richter V.A. (1970): Sem. Ulidiidae. In: Bei-Bienko G.Y. (ed.): Opredelitel nasekomykh evropeiskoi chasti SSSR. Vol. 5, Part 2, Nauka, Leningrad, pp. 130-132. [In Russian]

Rozkošný R. \& Spitzer K. (1965): Schnepfenfliegen (Diptera, Rhagionidae) in der Tschechoslowakei. - Acta entomologica bohemoslovaca 62: 340-368.

Říha M. (2017): Species diversity and habitat preferences of Aculeata (Insecta: Hymenoptera) of urban and suburban gardens in Brno city (Czech Republic). - Acta Universitatis Agriculturae et Silviculturae Mendelianae Brunensis 65: 171-178.

Semelbauer M. (2016): Fauna Slovenska: Lauxaniidae - tieňovkovité (Diptera - Cyclorrhapha). Veda, 183 pp.

Silva N.M.D., Fantinel C.D.C., Valente V.L. \& Valiati V.H. (2005): Population dynamics of the invasive species Zaprionus indianus (Gupta) (Diptera: Drosophilidae) in communities of drosophilids of Porto Alegre city, southern of Brazil. - Neotropical Entomology 34(3): 363-374.

Söli G. \& Rindal E. (2014): The genus Sylvicola Harris, 1780 (Diptera, Anisopodidae) in Norway - with a key to the North European species. - Norwegian Journal of Entomology 61: 190-200.

Stackelberg A.A. (1970): Clusiidae. In: Bey-Bienko G.J. (ed.): [A key to the identification of insects of the European part of the USSR]. Vol. 5(2). Nauka, Leningrad, pp. 303-305. [In Russian]

Šustek Z. \& Stanko M. (2012): Beetles (Insecta: Coleoptera) in the nests of mound-building mouse Mus spicilegus in four orographic units in Slovakia. - Oltenia Journal for Studies in Natural Sciences 28: 66-78.

Van der Weele R., Manko P. \& Oboňa J. (2018): Two new species of hybotid flies (Platypalpus sloveniensis Bequaert, 1962 and Tachypeza tanaisense Kovalev in Chvála, 1975) for the fauna of Slovakia. - Biodiversity \& Environment 10 (2): 18-21.

Withers P. (1988): Moth flies Diptera: Psychodidae. - Dipterists Digest 4: 1-83. 
Authors' addresses: Jozef Oboňa, Laura Mlynárová, Peter Manko, Department of Ecology, Faculty of Humanities and Natural Sciences, University of Prešov, 17. novembra 1, SK-08116 Prešov, Slovakia.

E-mails: laura.mlynarova@smail.unipo.sk, peter.manko@unipo.sk

Paul L. Th. Beuk, Natuurhistorisch Museum Maastricht, De Bosquetplein 7, NL-6211

KJ Maastricht, the Netherlands.

E-mail:paul.beuk@maastricht.nl

Kateřina Dvořáková, Libor Dvořák, Tři Sekery 21, CZ-35301 Mariánské Lázně,

Czech Republic.

E-mails: K.Marsova@seznam.cz, lib.dvorak@seznam.cz

Patrick Grootaert, Royal Belgian Institute of Natural Sciences, BE-1000 Brussels, Belgium \& National Biodiversity Centre, National Parks, Singapore; Lee Kong Chian Natural History Museum, National University of Singapore, SI-117377 Singapore. Email:pgrootaert@yahoo.co.uk

Jean-Paul Haenni, Muséum d'histoire naturelle, Rue des Terreaux 14, CH-2000 Neuchâtel, Switzerland.

E-mail: Jean-Paul.Haenni@unine.ch

Jan Ježek, National Museum, Department of Entomology, Cirkusová 1740, CZ-19300

Prague 9 - Horní Počernice, Czech Republic.

E-mail: jan.jezek@o2active.cz

Ruud van der We ele, Kloosterlaan 6, NL-4111 LG Zoelmond, the Netherlands. E-mail: rvanderweele@gmail.com

*Corresponding author: jozef.obona@unipo.sk 